Article

\title{
Environmental Challenges, Opportunities, and Policy Implications to Materialize China's Green Belt and Road Initiative
}

\author{
Tiantian Zhai $\mathbb{D}$
}

Citation: Zhai, T. Environmental Challenges, Opportunities, and Policy Implications to Materialize China's Green Belt and Road Initiative. Sustainability 2021, 13, 10428. https:// doi.org/10.3390/su131810428

Academic Editor: Ioannis Nikolaou

Received: 10 July 2021

Accepted: 16 September 2021

Published: 18 September 2021

Publisher's Note: MDPI stays neutral with regard to jurisdictional claims in published maps and institutional affiliations.

Copyright: (C) 2021 by the author. Licensee MDPI, Basel, Switzerland. This article is an open access article distributed under the terms and conditions of the Creative Commons Attribution (CC BY) license (https:/ / creativecommons.org/licenses/by/ $4.0 /)$.
School of Law, Shandong Normal University, Jinan 250358, China; zhaitiantian@sdnu.edu.cn

\begin{abstract}
China's Belt and Road Initiative (BRI), announced in 2013, is an unprecedented megaproject that aims to improve connectivity between China and over 70 countries through infrastructure investment and regional cooperation. It has unparalleled potential to bring about positive economic development across vast regions of the world but, at the same time, may inevitably come with considerable environmental challenges. Even so, opportunities exist to prevent or mitigate environmental risks and realize China's promise of a green BRI. China has proposed to construct a green BRI. The existing environmental law framework of host states, green development practices by China and BRI participating countries, and the role of bilateral investment treaties (BITs) as well as multilateral environmental agreements (MEAs) all increase the odds of a green BRI. This article contributes to existing BRI-related literature by examining the environmental challenges and opportunities of the BRI and providing suggestions on building a comprehensive environmental protection mechanism. It is suggested to stringently implement environmental norms and green BRI policies, make greater use of BITs and MEAs, bring together various actors, mobilize all available resources, and establish an efficient environmental dispute settlement and environmental remediation system.
\end{abstract}

Keywords: belt and road initiative; environmental challenges; environmental opportunities; green belt and road; comprehensive environmental protection mechanism; China

\section{Introduction}

The Belt and Road Initiative (BRI), encompassing the Silk Road Economic Belt and 21st Century Maritime Silk Road, is a large-scaled economic and geopolitical strategy launched by China in 2013, aiming to facilitate trade and promote connectivity and cooperation among countries in Eurasia and some African countries. The "Vision and Actions on Jointly Building Belt and Road," released by the Chinese government, has defined five priority areas for cooperation: policy coordination, facilities connectivity, unimpeded trade, financial integration, and people-to-people bond [1]. As of 23 June 2021, China has signed 206 BRI cooperation documents with 140 countries and 32 international organizations [2].

As a global economic cooperation initiative involving more than 70 countries that account for two-thirds of the world's population and one-third of global GDP [3], the BRI could provide unprecedented economic cooperation opportunities and has revealed unparalleled economic potentialities, especially in accelerating economic growth of povertystricken areas under the BRI framework. According to the estimation of the World Bank Group (WBG), if completed, BRI transport projects alone could reduce travel times along economic corridors by 12 percent and with the rest of the world by an average of three percent; increase trade between 2.8 percent and 9.7 percent for corridor economies and between 1.7 percent and 6.2 percent for the world; and increase income by up to 3.4 percent, lifting 7.6 million people from extreme poverty and 32 million from moderate poverty [4] (p. XIII). Therefore, the BRI has become a big attraction to countries in such regions as Central Asia [5]. 
Despite those potential economic benefits, such a large, cross-border project entailing the expansion and upgrading of such colossal infrastructure as roads, railways, airports, ports, power stations, and pipelines, comes with considerable risks. In addition to causing possible economic issues to local communities, such as disproportionally reallocating economic benefits and losses [6], it may pose daunting environmental and climate challenges. China has proposed to construct a green BRI [7], but still, possible environmental repercussions, such as worsening pollution, depleting resources, and sabotaging land, water, and wildlife as well as escalating climate change, have become a cause for deep concern and a target for criticism [8-10]. Many scholars have pointed out the BRI's potential impact on global greenhouse gas emissions in the future [11,12]. It is blamed for hindering the realization of the emissions targets in the Paris Agreement [13-15] and tipping the world into catastrophic climate change [16].

Having said that, those environmental challenges can be turned into opportunities for environmental stewardship and provide China with a chance to promote its view of ecological societies $[13,14]$ if a well-designed, comprehensive environmental protection mechanism is put in place. For such a sustainable scenario, BRI needs to capitalize on and further existing opportunities for green development, including green BRI policies, environmental norms, and green development practices of China and participating countries BITs as well as international environmental law framework.

This article has strong policy implications for government regulators, policymakers and BRI investors. Contributing to the literature on the BRI, this article aims to examine the environmental challenges and opportunities of the BRI and provide corresponding policy implications on the construction of a comprehensive environmental protection mechanism for the BRI. It provided the following suggestions: (1) stringently implement environmental norms and green BRI policies; (2) make greater use of BITs and MEAs; (3) bring together various actors and mobilize all available resources; and (4) establish an efficient environmental dispute-settlement and environmental remediation system.

The rest of this article is organized as follows: the second section introduces the research methods, the third section discusses the environmental challenges confronted by the BRI, and the fourth section analyses potential environmental opportunities. On this basis, the fifth section puts forward policy implications to build a comprehensive environmental protection mechanism for the BRI. Finally, the sixth section concludes this article.

\section{Research Methods}

To achieve the research objective, that is, to find out the environmental challenges and opportunities of the BRI and to provide suggestions on addressing such challenges, this research mainly employed qualitative research methods.

The research process was divided into three steps. The first step was to collect data and information. To ensure the authenticity and credibility of those data and information, the researcher carefully selected the source basis. It downloaded policy documents concerning the BRI from the official website of the Chinese government, such as that of the State Council and the Department of Commerce of the People's Republic of China. It investigated BITs between China and BRI-participating countries, existing MEAs that may contribute to the greening of the BRI, and BRI-related cases with the commonly used legal research tool, Thomson Reuters Westlaw. The research referred to pertinent academic research from the trusted citation database Web of Science. It also collected data produced by the World Bank Group, the World Wildlife Foundation, the National Resources Defence Council, and the World Resources Institute, etc., from their official websites, respectively. More importantly, to ensure that relevant data truly represent the case of China and the BRI, the researcher cross-checked data from different sources. For instance, as regards the MEAs China has acceded to, it checked both Westlaw and the University of Oregon International Environmental Agreements (IEA) Database to ensure data consistency. Moreover, to reduce the impact of potential biases, it not only collected news released by the Chinese media, 
such as China Daily and Xinhua News, but also examined western media coverage, such as the Guardian.

The second step was to select the fitting data, ideas, and themes and to systematically categorize them into different sections of the research topic so as to make preparations for further analysis. Based on the first two steps, the third step was to explore the research topic in detail and carry out in-depth analysis. During this process, a set of analytic strategies of qualitative research were applied, including document analysis, data analysis, and case studies. Document analysis has evolved into one of the most used qualitative methods in nearly every field. In this research, it mainly refers to the examination, interpretation, and evaluation of governmental policy documents, news, existing academic research, and relevant legal documents, such as BITs and MEAs. Data analysis in this research includes analysis of both qualitative data and quantitative data originally produced by existing research. In addition, this research also cited and analysed a series of BRI environmental cases as empirical evidence. All these analytic strategies were designed to identify potential environmental challenges and opportunities of the BRI and to come up with feasible means of materializing a green BRI, which constitutes the purpose of this research.

\section{Environmental Challenges of the BRI}

As with other major infrastructure projects, the BRI is inevitably fraught with environmental challenges. Most of BRI participating countries are developing countries featuring varied environment and climates with prominent ecological issues, and some countries prioritizing economic development have not paid adequate attention to environmental protection. The implementation of the BRI may make matters worse. Infrastructure construction and energy exploitation may further increase the discharge of pollutants and consumption of resources, including the extraction and use of raw materials and exploitation of oil and gas reserves that may exceed the rate of renewal. It may also negatively impact biodiversity by chopping up habitats, increasing wildlife mortality, pollution, and spread of invasive species, as manifested by the preliminary spatial analysis of the World Wildlife Fund (WWF) [17].

Besides, many BRI routes run through geodynamically active areas that are vulnerable to flooding, soil erosion, landslides, and sedimentation in rivers. Examples are the RussiaChina Amur Bridge transport corridor that dissects two nature reserves with pristine forests [18] and the Karakoram Highway that traverses one of the most geodynamic regions on earth, posing risks to earthquakes, landslides, flooding, etc. [19-21].

Apart from those direct environmental effects of the BRI to different components of the Earth system, including atmosphere, hydrosphere, geosphere, and biosphere [22], landscape connectivity and land-use changes may also lead to indirect effects. For instance, the construction of roads and railways lowers transport costs and thereby shifts markets and human populations, which may lead to illegal poaching, logging, and other economic and environmental effects [4] (p. 112).

Furthermore, those types of environmental repercussions may also threaten the livelihood of people who rely heavily on local environmental resources, with a negative spillover into fisheries, farming, and agriculture [23]. For example, the Sambor hydroelectric dam backed by China Southern Power Grid Company was reported to have blocked fish migration, devastated fisheries of downstream countries, and prevented riverbed sediment that fertilizes the Mekong Delta rice bowl. Dams already built in China's section of the Mekong river were also blamed for exacerbating a Southeast Asian drought [24]. Ultimately, such environmental threats posed by BRI projects may draw fierce local condemnation and protests, especially from activists and environmentalists, which would, in return, stigmatize the BRI and block its progress. For instance, the construction of a hydroelectric dam on the island of Sumatra, Indonesia, in 2018 encountered intense opposition for fragmenting habitats, threatening local livelihoods and causing risks of earthquakes [25].

Another impact of the BRI engendering more concern is that it may increase greenhouse gas emissions and constitute a challenge to achieving the objectives of the Paris 
Agreement. China has great potential for and has largely increased BRI investments in renewable energy with the latest technology [26], but a larger share of BRI projects are oil, gas, and coal focused. According to a report by the World Resources Institute and Boston University's Global Development Policy Centre, out of China state policy banks' loans in the energy sector for the BRI from 2014 to 2017, coal power, nuclear power, and hydropower loans combined are almost seven times more than loans to solar and wind [27]. The World Bank Study concludes that BRI transport infrastructure is estimated to increase carbon dioxide emissions by 0.3 percent worldwide—-but by seven percent or more in countries like Cambodia, Kyrgyz Republic, and Lao PDR as production expands in sectors with higher emissions [4] (p. 7).

\section{Opportunities for Environmental Protection under the BRI}

While the BRI, as a mega-infrastructure initiative, might pose new and grave environmental threats to the economic corridors and beyond, opportunities abound of managing the BRI properly and responsibly, rendering it possible to keep environmental risks under control without sacrificing the massive economic growth potential of the BRI.

\subsection{Baseline Protection by the Environmental Laws and Regulations of Host States}

To start with, host governments' policies regulate the execution of the green BRI scheme, and host states' laws and regulations may provide at least minimum protection against environmental risks posed by BRI projects.

On 29 January 2019, the Ministry of Commerce of China (MCC) officially published the Guidelines for Country-by-Country (Region-by-Region) Foreign Investment and Cooperation [28]. In addition to introducing the political, economic, cultural, and geographical conditions of 172 countries (all BRI-participating countries included) and prioritizing the development of a green BRI, the Guidelines also include environmental laws and regulations of BRI host states.

China has promised to comply with the laws and regulations of host states for all BRI projects, so theoretically, these norms can serve as the first line of defence against environmental repercussions caused by the BRI if they are enforced with deliberations on site selection, consultation, social impact, displacement, and long-term impacts, etc.

\subsection{China's Green BRI Policies in Line with the UN 2030 Sustainable Development Goals (SDGs)}

Compliance with host states' environmental laws and regulations ensures that BRI projects meet local environmental requirements, while China's green BRI policies that are linked to the UN 2030 SDGs $[29,30]$ make it possible to adhere to the highest international environmental standards. China asserted that the BRI would be green, and it has proposed broad policies to support this pledge.

As early as 2015, China has brought up a domestic "Ecological Civilization" reform plan [31] backed by a series of new environmental policies, including a strengthened Environmental Protection Law [32], to resolve its environmental crisis. After the Paris Agreement, China made a shift in its energy policy, with increasing emphasis on green development promoting technological innovation and renewables [33]. In October 2017, during the 19th CPC National People's Congress, President Xi Jinping further emphasized "speeding up reform of the ecological civilization system and building a beautiful China" [34]. To link those ecological civilization principles to the BRI, China has envisaged the idea of a "green BRI" and tried to make it materialize.

In addition to existing Guidelines emphasizing Chinese enterprises' responsibility of environmental protection in foreign investment and cooperation [35,36], the 2015 "Vision and Actions on Jointly Building Belt and Road" particularly highlighted ecological civilization during BRI investment and trade and increased cooperation in environmental conservation, biodiversity protection, and climate-change actions [1]. The 2017 "Guidance to Promote Green Belt and Road" is regarded as another encouraging step in boosting a green BRI. It dictates that the BRI should "follow the principle of being resource efficient 
and environment friendly; embed the green concept into the efforts in policy coordination; facility connectivity, unimpeded trade, financial integration, and people-to-people bonds; and incorporate environmental protection into all aspects and the whole process of the Belt and Road building" [37].

During the first BRI forum in May 2017, the Chinese government declared the BRI would promote the Paris Agreement and UN SDGs and asserted the BRI as a "vision of green development and a way of life and work that is green, low-carbon, circular, and sustainable" [7]. As an official document released from the first forum, "The Belt and Road Ecological and Environmental Cooperation Plan" (Environmental Cooperation Plan) accentuated the significance of environmental cooperation in building a green BRI, facilitating the green transformation of corridor economies and implementing the UN 2030 SDGs. It pointed out the overarching requirements of BRI environmental cooperation and elaborated specific schemes in policy coordination, green infrastructure, green trade, green finance, people-to-people bonds, and capacity building [38]. In the same year, the "Vision for Maritime Cooperation under the Belt and Road Initiative" was also released, which particularly emphasized strengthening BRI maritime cooperation to protect and sustainably utilize marine resources and enhance marine welfare [39]. During the second BRI forum in April 2019, 27 financial institutions around the world, including all major Chinese banks involved in the BRI, signed the "Green Investment Principles" [40], with the expectation of more signatories in the future. The Green Investment Principles include embedding sustainability into corporate governance, understanding environmental, social and governance risks, disclosing environmental information, enhancing communication with stakeholders, utilizing green financial instruments, adopting green supply chain management, and building capacity through collective action. They aim to ensure that "environmental friendliness, climate resilience, and social inclusiveness are built into new investment projects in the Belt and Road" [40].

\subsection{Green Development Practices by China and BRI Participating Countries}

Apart from broad green BRI policies, China has been translating those sustainable objectives into concrete actions, such as increasing green energy investment, advancing cooperation, and exchanging reference experience with BRI-participating countries on environmental protection. Those green development practices exhibit another promising dimension for a green BRI.

As a world leader in renewable energy [33], China has a window of opportunity to scale up renewable energy investments through the BRI. As pointed out in a recent report by Natural Resources Defence Council (NRDC), from 2008 to 2017, the global average annual growth rate of wind- and solar-power installed capacity was 19 percent and 46 percent, respectively. China's average annual growth rate of wind- and solar-power installed capacity reached 44 percent and 191 percent, respectively, laying a solid foundation for China's renewable energy cooperation with BRI countries [26]. It is estimated that the total installed capacity of renewable energy in 38 countries along the BRI route could reach $644.334 \mathrm{GW}$ from 2020 to 2030, and total investment in wind and solar power could reach $\$ 644.334$ billion. China has formed an international development cooperation model for renewable energy, which focused on six BRI economic corridors and China-Africa cooperation. Typical examples include the Sweihan Photovoltaic Project jointly developed by China's JinkoSolar and Japan's Marubeni in Abu Dhabi, UAE and Sinomatch and General Electric's cooperation on a $102 \mathrm{MW}$ wind power demonstration project in Kapedo, Kenya, etc. [26]. Therefore, China's massive potential in renewable energy investment can not only go a long way in helping BRI countries meet their domestic clean energy targets under the Paris Agreement, but it can also greatly contribute to the reduction of global carbon emissions [41].

Moreover, in order to enhance international cooperation and share international experience, China launched, in partnership with the United Nations Environment Program, the BRI International Green Development Coalition (BRIGC) in April 2019 [42]. It develops 
ten thematic partnerships and has over 130 partners by May 2019, including national environmental authorities, international organizations, research institutions, and businesses [43]. The BRIGC showcases advanced work and provides insights in pollution treatment, the management and conservation of ecosystem, green energy, green production, green lifestyles, green finance, etc. [44], for example, the treatment of sewage in Israel, the restoration of coast in Indonesia, the Karot Hydropower project in Pakistan, the Esquel Plant in Vietnam Industrial Park, the Eco-label of the Republic of Korea, and the solar-powered mill program in Zambia. Most of the cases were from cooperative projects as well as practices by BRI-participating countries. They demonstrate the cooperative efforts within and between BRI-participating countries as well as among stakeholders and may further enhance green consensus, boost confidence in green BRI, and spawn more down-to-earth practices for green development [44].

\subsection{BITs and MEAs}

BITs, by setting down stable and predictable legal framework, have become one of the most widely used types of international agreements for protecting and influencing foreign investments [45]. They may also promote environmental protection in host states by provisions on or references to sustainable development in general, or more specifically, to the protection of the environment [46]. BITs may also play a significant role in greening BRI investments by clarifying environmental standards; specifying environmental rights, obligations, and accountability of the contracting parties; incorporating cooperation on green technologies; as well as establishing an efficient environmental dispute-settlement or environmental restoration mechanism. By December 2016, China had signed BITs with 104 countries [47], providing another channel for BRI host states to promote economic development without compromising on environmental protection.

MEAs, as an effective form of international environmental governance, play a key role in addressing regional and global environmental issues and are another important choice to combat BRI environmental risks, especially under the circumstances where China has not signed any BIT with some countries along the Belt and Road. The good news is that in recent years, China has assumed an increasingly elevated role in global environmental protection by signing and ratifying a series of MEAs [48]. China also emphasizes cooperation for compliance with environmental agreements in the "Environmental Cooperation Plan" of BRI, determined to "help relevant countries along the Belt and Road to fulfil commitments under MEAs, such as Convention on Biological Diversity and Stockholm Convention on Persistent Organic Pollutants, by building up cooperation mechanisms for MEAs implementation and enabling technological exchange and South-South cooperation" [38]. Adherence to those MEAs by China and BRI participating countries may largely contribute to the management of BRI environmental risks and the greening of the projects that are developing or will be developed along the BRI corridors.

\section{Policy Suggestions for Materializing a Green BRI}

Current environmentally sound institutional arrangement and practical endeavours increase the odds that BRI projects are green-development oriented. However, addressing environmental issues associated with the BRI is tremendously complex and, accordingly, entails a more comprehensive environmental-protection mechanism. Such a mechanism necessitates both institutional design in broad strokes and effective implementation in a piecemeal fashion. It combines exertions at both domestic and international levels, maximizes the role of all possible participants, and facilitates the settlement of environmental disputes as well as the restoration of degraded ecosystems. To that end, this research puts forward some suggestions as follows.

\subsection{Stringently Implementing Environmental Norms and Green BRI Policies}

Existing environmental laws and regulations of participating countries may provide baseline environmental protection in the BRI domain, and China's vigorous policy support 
presents another promising prospect for a green BRI. Yet for all this, good environmental performance all comes down to stringent implementation, which depends critically on the synergy between concrete environmental standards and local government's willingness and capacity to follow through.

First of all, China should translate its grand and aspirational green BRI statements into concrete principles and standards. The robust green BRI policies pledged by China represent its commitment to fight against environmental risks and an ambitious vision for a green BRI. However, the overarching requirements under BRI's underlying sustainability framework, by their very essence, are generic domestic policies, lacking detailed and binding mechanisms for implementation, monitoring, and enforcement. Unless made mandatory overseas, chances are high that those eco-friendly guidelines will eventually fall through the cracks. Therefore, China is not only required to come up with a green, low-emissions, and sustainable BRI framework in the areas of policies, infrastructure, trade, finance, culture, etc., but what is more important is to translate it into concrete green investment standards.

For instance, emphasis on enterprises' environmental responsibility should not be confined to voluntary guidelines that encourage investors to comply with local environmental norms, strengthen environmental management, or disclose more environmental information [38]. Rather, it should refine standards to intensify the monitoring and enforcement of the Chinese foreign investment laws regarding environmental protection and hold Chinese banks and companies liable for disregarding environmental standards overseas. Only by doing so can it ensure that all BRI participants and stakeholders, particularly Chinese investors, rigorously and concisely adhere to those environmental norms in every BRI project.

The establishment of concrete standards may necessitate the co-efforts of multiple regulatory authorities, such as the Ministry of Commerce (MCC), the National Development and Reform Commission (NRDC), the Ministry of Ecology and Environment (MEEC), the Ministry of Finance, and the China Banking and Insurance Regulatory Commission. One suggestion is that all BRI-related projects implemented outside China adhere to the environmental standards China applies at home [14], while another possible way is to follow the high standards applied by such international financial institutions as the World Bank [49].

Second, to yield the best environmental outcomes, strategic environmental standards must converge with robust local enforcement. On the one hand, China is required to create more incentives for local governments' active enforcement and to discourage environmental "race to the bottom". This may include providing compensatory payments to local governments in return for reducing pollution and maintaining ecosystems. Green financing and insurance is another incentive tactic that prioritizes renewable energy projects, utilizes advanced and efficient technology for energy transmission infrastructure, supports the development of public transit systems, and holds project developers to high environmental governance standards. On the other hand, China needs to help improve local governments' environmental governance capacity by such means as enhancing cooperation on environmental technologies and sharing cutting-edge environmental assessment tools, deepening collaboration on pollution control and ecological conservation, and providing support in environmental policy and legislation, personnel exchanges, and green projects demonstrations, etc.

Furthermore, the efficacy of environmental norms and green BRI policies is subject to the involvement of credible Strategic Environmental Assessments (SEAs) and environmental impact assessments (EIAs). Well-established SEAs systematically evaluate the environmental consequences of BRI policies, planning, and programs, while EIAs help to avoid detrimental environmental impacts of every BRI project. Both of them should be incorporated into the earliest possible stages of decision making so that environmental impacts could be addressed on a timely and appropriate basis. A negative example is that 
Chinese-owned Amazar Forest Complex in the Zabaikalsky Province of Russia is stalled for lack of comprehensive SEA/EIA at the outset [50].

Besides, transparency is another principle that must be upheld to reduce enforcement deficits. More public information should be provided during the planning, financing, and procurement processes of BRI projects so that legal practitioners, media, activists, and the public could freely question the government and enterprises in case of possible environmental impacts, thereby encouraging community involvement, bolstering public trust in investment decisions, and helping build positive local perceptions of China and the BRI [5] (p. 127).

\subsection{Making Greater Use of BITs and MEAs}

Although China has signed a vast array of BITs, including those signed with many BRI participating countries, there are few containing BRI-specific environmental protection provisions. Therefore, in view of BRI environmental risks, China needs to re-examine those BITs and revise them if necessary, especially those signed with countries with the most Chinese investment. It is required to incorporate more detailed environment protection provisions according to local environmental protection requirements. Such provisions should contain specific environmental standards and transparent decision-making procedures for each BRI project. During this process, the environmental standards and practices recognized by the international community through various MEAs represent a good reference value [51]. It is also necessary to emphasize the environmental governance of host states, elucidate enforceable environmental obligations of investors, and establish relevant dispute-settlement mechanisms. What is particularly important, inter alia, is to clearly stipulate investors' environmental obligations in BITs. Those obligations may serve as the legal basis for host-state environmental counterclaims that are regarded as a chance for host states to "put environmental considerations on equal footing with trade and investment concerns" [52] and a reminder for investors to sharpen environmental risk perception during BRI investments.

MEAs, referred to by scholars and practitioners as "soft laws", form the overarching legal basis for global environmental governance. By complementing national legislation and bilateral or regional agreements, their role in achieving sustainable development has long been recognized [53]. Currently, the number of MEAs has reached over 1300 [48], and a substantial number of them, such as the Paris Agreement on tackling climate change, are important international legal instruments that should also steer the design and implementation of the BRI.

To make greater use of MEAs in greening the BRI, China should make further efforts in the following two aspects. First, China needs to effectively implement the already signed MEAs by translating them into BRI-related policies, strategies, actions, and enforcement tools, such as legislation, bilateral or regional agreements, and technical and financial measures [54]. Second, China should pay attention to other MEAs highly relevant to the $\mathrm{BRI}$ and consider ratifying them when the timing is right [50]. Examples of those MEAs include the UNECE Water Convention (ratified by 41 BRI countries) [55], the UNECE Espoo EIA Convention and its SEA Protocol (ratified by 44 and 31 BRI countries, respectively) [56,57], the UNECE Aarhus Convention (ratified by 46 BRI countries) [58], and the Bonn Convention on the Conservation of Migratory Species of Wild Animals (the CMS Convention, ratified by 65 BRI countries) [59].

For instance, as stated earlier, environmental assessment tools, such as EIAs and SEAs, are vital to preventing possible negative environmental impacts of BRI projects. The construction of infrastructure facilities and the harmonization of spatial-planning schemes along the economic corridors are virtually impossible without the use of those techniques. Although both are mandatory in China domestically, China has not signed the UNECE Espoo EIA Convention and its SEA Protocol as a binding international legal instrument for its overseas projects. Additionally, WWF BRI Spatial Analysis of IUCN Red List data shows that BRI corridors overlap with the range of 265 threatened species, 
including 39 critically endangered species and 81 endangered species [17], yet China has not signed the CMS Convention, which is the only global Convention specializing in the conservation of migratory species, their habitats, and migration routes. Therefore, if China could ratify those Conventions in the future and apply them to the implementation of the BRI, it would largely elevate the sustainability of BRI projects.

\subsection{Bringing Together Various Actors and Mobilizing All Available Resources}

The achievement of a green BRI requires not only the efforts of China and the governments of participating countries but also the collective wisdom and strength as well as continuous endeavours from all parties, including the UN system and other international organizations, NGOs, think tanks, private actors, and civil society, etc. Those various actors may facilitate the building of a green BRI in three ways.

First, enhancing multilateral cooperation and popularizing green development practices. A typical example is the establishment of the BRIGC that provides a communication platform for all BRI stakeholders, showcases advanced work and insights on green development, and increases green consensus. Besides, the Green Silk Road Initiative Declaration put forward by a group of 20 NGOs from 11 countries in 2016 further demonstrates their role in unifying civil society and pushing for BRI's adherence to the concept of ecological civilization, employment of environmentally sound development strategies, and adoption of green economy and green finance mechanisms [60].

Second, providing environmental governance standards and policy recommendations for BRI projects. For example, the governance norms and environmental standards established by international banks, such as the World Bank's Environmental and Social Framework [49], if adopted, could stimulate BRI project developers to comply with the highest international social and environmental standards and to better manage environmental and social risks. Besides, the BRI recommendations and spatial analysis by the WWF, with its expertise and credibility in several subjects critical to the BRI, is also instrumental in mitigating potential negative environmental impacts of BRI projects [17].

Third, promoting green technology and sharing environmental information. The role of such think tanks as environmental and scientific research institutions in developing cutting-edge green technology and environmental assessment tools for the BRI cannot be overstated. For instance, the big Earth data project launched by the Chinese Academy of Sciences in 2018 could serve as a BRI environmental information sharing platform that provides comprehensive information support for eco-friendly Belt and Road and enhances advisory services for environmental risk assessment and prevention [61].

Therefore, if the BRI could give full play to the role of all possible participants and mobilize all available resources during its implementation, it would move a further step towards the achievement of its green objectives.

\subsection{Establishing an Efficient Environmental Dispute-Settlement and Environmental Remediation System}

Generally speaking, an investor and its host state may submit unsolved environmental disputes to a local court or to a third-party arbitral tribunal to adjudicate on the violation of environmental obligations under the investment treaty and the specific liability of the violator. Compared with litigation, international arbitration has unparalleled advantages in impartiality, confidentiality, efficiency, and enforceability.

First, with neutrality, independence, and impartiality as the central themes in the arbitral process, arbitration offers a neutral forum, with neither party having the advantage of their local court, thus allowing the parties to experience a fair process and attain a just outcome [62]. Second, in contrast to publicity in litigation, most arbitral rules do not allow for public attendance or public access to the parties' filings in the case. Accordingly, arbitration offers a key advantage over litigation by ensuring a greater level of confidentiality that is particularly important to many investment and business transactions. Third, unlike trials, which must be worked into overcrowded court calendars, arbitration is more flexible in time, and as opposed to the convoluted rules of evidence and procedure required in 
litigation, arbitration proceedings are often simplified and more easily adapted to the needs of those involved, rendering arbitration a more efficient way to resolve disputes. Last but not least, due to the landmark treaty, Convention on the Recognition and Enforcement of Foreign Arbitral Awards (the New York Convention) [63], an international arbitral award is enforceable virtually worldwide, while a judgment from a national court is often only enforceable in the nation that issued it. A good example is that Chinese courts recognized and enforced 86.4 percent of international arbitral awards presented to them from 2011 to 2015 [64].

Due to the above advantages, international arbitration has enjoyed increasing popularity as an alternative to litigation in court and has become the mainstream in resolving foreign investment disputes [65]. Therefore, it is highly recommended to choose arbitration as the best means to resolve investment disputes including environmental disputes arising under the BRI. To yield a predictable and more enforceable outcome, the contracting parties may agree beforehand on the choice of arbitral institutions, the applicable law, and matters relating to the enforcement of arbitral awards. Depending on the location of the parties and the characteristics of potential disputes, there are many arbitral institutions that can be considered, such as International Chamber of Commerce (ICC), International Centre for Settlement of Investment Disputes (ICSID), Arbitration Institute of the Stockholm Chamber of Commerce (SCC), Swiss Chambers Arbitration Institution, London Court of International Arbitration (LCIA), China International Economic and Trade Arbitration Commission (CIETAC), etc. On the part of the arbitral tribunal, it shall conform to the principle of sustainability while settling BRI environmental disputes, striking a balance between investor protection and the environmental interest of the host state and of the globe at large, thereby contributing to global environmental governance.

Apart from an efficient dispute resolution mechanism, it is also of great necessity to establish an effective environmental remediation system which, compared with ex ante environmental risk-control measures, ensures the restoration or compensation of the damaged environment and ecosystem in a timely and efficacious manner. In general, such a mechanism is composed of three levels of remediation. First, primary remediation aims to return the damaged environment and/or impaired services to baseline condition by taking such remedial actions as stabilizing damaged slopes and replanting vegetation. Second, complementary remediation, such as off-site remediation, occurs when primary remediation does not result in full in-situ restoration. Third, compensatory remediation compensates for interim losses of natural resources and/or services that occur during restoration [65]. The specific environmental remediation mechanism under the BRI may be set up through intergovernmental cooperation agreements or the BIT between the BRI investor and the host state by reference to relevant domestic legislation [66-69] or international environmental conventions [70,71].

\section{Conclusions}

The BRI is an unprecedentedly ambitious development plan that promises prosperity to participating countries and contributes to the global economy as well. As BRI projects move steadily from a blueprint to realization, it remains to be seen whether China will be able to realize its promise of a green BRI. Regardless, it is clear that, as such a wide-ranging and all-encompassing program, the BRI is destined to shape the environmental future of many nations and of our planet for decades to come.

Despite its possible negative environmental impacts, the BRI should be put into perspective. Overall, the economic gains of the BRI and its possible contributions to the world may largely outweigh its negative impacts, and those possible environmental repercussions can be significantly prevented or mitigated if the green BRI scheme is well enforced, and proper measures are effectively taken. To date, by virtue of the existing legal framework, a host of green development policies and practices as well as the signing of a variety of BITs and MEAs, China has cultivated promising opportunities to responsibly and 
properly manage the environmental impacts of the BRI and to produce positive spill-over effects on future global infrastructure development programs.

However, to reap the full benefits of the BRI and translate green BRI objectives to real progress, current efforts are not enough. Generally, the achievement of a green BRI calls for a more comprehensive environmental protection mechanism. To be specific, the implementation of BRI projects should stringently comply with existing environmental norms and green BRI policies of China and participating countries. For that purpose, China needs to put its high-flown green BRI pledges into mandatory and detailed environmental standards, to stimulate robust local enforcement, and enhance local environmental governance capacity by all means. It is also vital to take full advantage of BITs and MEAs as effective legal instruments to mandate environmental protection by incorporating BRIspecific environmental provisions into BITs, effectively implementing the already signed MEAs, and, if feasible, ratifying more BRI-related MEAs in the future. In addition to actions on the governmental level, the role of various actors, such as organizations, private actors, thinks tanks, and civil society, should not be underestimated. Finally, it is imperative that an efficient environmental dispute resolution and environmental remediation system be put in place so as to ensure the accountability of environmental saboteurs and the effective restoration of the degraded ecosystem. To that end, international arbitration has become a preferable alternative to litigation, and specific environmental remediation mechanism can be elaborately designed by reference to a pertinent domestic or international legal framework.

Admittedly, responding to the environmental challenges of the BRI is a complex project with variance and uncertainties in politics, law, economy, history, geography, etc. While this article just sketches out possible policy recommendations, especially from the legal perspective, it provides a good starting point for discussion, and future studies could take a deeper dive into this issue through other different lenses.

Funding: The work was funded by the Social Science Planning Program of Shandong Province (Grant No. 21DFXJ06).

Institutional Review Board Statement: Not applicable.

Informed Consent Statement: Not applicable.

Data Availability Statement: Not applicable.

Conflicts of Interest: The author declares no conflict of interest.

\section{References}

1. NDRC; MFA; MCC. Vision and Actions on Jointly Building Belt and Road. 28 March 2015. Available online: http://www. beltandroadforum.org/english/n100/2017/0410/c22-45.html (accessed on 7 February 2021).

2. Belt and Road Portal. List of Countries that Have Signed One Belt and One Road Cooperation Documents with China. Available online: https: / / www.yidaiyilu.gov.cn/gbjg/gbgk/77073.htm (accessed on 12 March 2021).

3. Ruta, M. Three Opportunities and Three Risks of the Belt and Road Initiative. Wold Bank Blogs. 4 May 2018. Available online: https://blogs.worldbank.org/trade/three-opportunities-and-three-risks-belt-and-road-initiative (accessed on 7 February 2021).

4. WBG. Belt and Road Economics: Opportunities and Risks of Transport. Corridors; World Bank Publications: Washington, DC, USA, 2019.

5. Vakulchuk, R.; Overland, I. China's Belt and Road Initiative through the Lens of Central Asia. In Regional Connection under the Belt and Road Initiative. The Prospects for Economic and Financial Cooperation; Cheung, F.M., Hong, Y., Eds.; Routledge: London, UK, 2019; pp. 115-133.

6. Mark, S.; Overland, I.; Vakulchuk, R. Sharing the Spoils: Winners and Losers in the Belt and Road Initiative in Myanmar. J. Curr. Southeast Asian Aff. 2020, 39, 381-404. [CrossRef]

7. Xinhua News. Full Text of President Xi's Speech at Opening of Belt and Road Forum. 14 May 2017. Available online: http: //58.194.172.13/rwt/157/http/P75YPLUZNFYGR7LBN3TYILUDN7XB/english/2017-05/14/c_136282982.htm (accessed on 7 February 2021).

8. EESI. Exploring the Environmental Repercussions of China's Belt and Road Initiative. 30 October 2018. Available online: https:/ / www.eesi.org/articles/view/exploring-the-environmental-repercussions-of-chinas-belt-and-road-initiativ (accessed on 7 February 2021). 
9. Ortolani, G. China's Belt and Road Poised to Transform the Earth, But at What Cost? 24 April 2018. Available online: https:/ / news.mongabay.com/2018/04/chinas-belt-and-road-poised-to-transform-the-earth-but-at-what-cost/ (accessed on 7 February 2021).

10. Spiegel, J.E. The Potential Climate Consequences of China's Belt and Roads Initiative. 17 February 2020. Available online: https:/ /yaleclimateconnections.org/2020/02/the-potential-climate-consequences-of-chinas-belt-and-roads-initiative/ (accessed on 7 February 2021).

11. Jun, M.; Zadek, S. A Low-carbon Belt and Road. 28 March 2019. Available online: https://www.project-syndicate. org/commentary / climate-change-belt-and-road-infrastructure-investment-by-ma-jun-and-simon-zadek-2019-03?barrier= accesspaylog (accessed on 7 February 2021).

12. Chen, Y.; Liu, S.B.; Wu, H.Q.; Zhang, X.L.; Zhou, Q. How Can Belt and Road Countries Contribute to Global Low-carbon Development? J. Clean. Prod. 2020, 256, 120717. [CrossRef]

13. Zhang, N.; Liu, Z.; Zheng, X.M.; Xue, J.J. Carbon Footprint of China's Belt and Road. Science 2017, 357, 1107. [CrossRef] [PubMed]

14. Ascensão, F.; Fahrig, L.; Clevenger, A.P.; Corlett, R.T.; Jaeger, J.A.G.; Laurance, W.F.; Pereira, H.M. Environmental Challenges for the Belt and Road Initiative. Nat. Sustain. 2020, 1, 206-209. [CrossRef]

15. United Nations. Paris Agreement to the United Nations Framework Convention on Climate Change; T.I.A.S. No. 16-1104; United Nations: New York, NY, USA, 2015.

16. Hilton, I. How China's Big Overseas Initiative Threatens Global Climate Progress. 3 January 2019. Available online: https: / / e360.yale.edu/features/how-chinas-big-overseas-initiative-threatens-climate-progress (accessed on 7 February 2021).

17. WWF. The Belt and Road Initiative: WWF Recommendations and Spatial Analysis. May 2017. Available online: https://go. nature.com/2v3SwoG (accessed on 17 March 2021).

18. Tracy, E.F.; Shvarts, E.; Simonov, E.; Babenko, M. China's New Eurasian Ambitions: The Environmental Risks of the Silk Road Economic Belt. Eurasian Geogr. Econ. 2017, 58, 56-88. [CrossRef]

19. Derbyshire, E.; Fort, M.; Owen, L.A. Geomorphological Hazards along the Karakoram Highway: Khunjerab Pass to the Gilgit River, Northernmost Pakistan. Erdkunde 2001, 55, 49-71. [CrossRef]

20. Laurance, W.F.; Goosem, M.; Laurance, S.G.W. Impacts of Roads and Linear Clearings on Tropical Forests. Trends Ecol. Evol. 2009, 24, 659-669. [CrossRef] [PubMed]

21. Johnstone, C.P.; Alan, L.; Richard, D.R. Habitat Loss, Fragmentation and Degradation Effects on Small Mammals: Analysis with Conditional Inference Tree Statistical Modelling. Biol. Conserv. 2014, 176, 80-98. [CrossRef]

22. Teo, H.C.; Lechner, A.M.; Walton, G.W.; Chan, F.K.S.; Cheshmehzangi, A.; Tan-Mullins, M.; Chan, H.K.; Sternberg, T.; Campos-Arceiz, A. Environmental Impacts of Infrastructure Development under the Belt and Road Initiative. Environments 2019, 6, 72. [CrossRef]

23. Lechner, A.M.; Chan, F.K.S.; Campos-Arceiz, A. Biodiversity Conservation Should Be a Core Value of China's Belt and Road Initiative. Nat. Ecol. Evol. 2018, 2, 408-409. [CrossRef] [PubMed]

24. US News. Study Says China-Backed Dam in Cambodia Would Destroy Mekong. 17 May 2018. Available online: https:/ / www.usnews.com/news/business/articles/2018-05-17/study-says-china-backed-dam-would-destroy-mekong (accessed on 9 February 2021).

25. Jong, H.N. Indonesian Activists Protest China-funded Dam in Orangutan Habitat. 9 May 2018. Available online: https:/ / news.mongabay.com/2018/05/chinas-plan-to-build-dam-in-rarest-apes-habitat-in-sumatra-condemned/ (accessed on 9 February 2021).

26. NRDC. Research on Renewable Energy Development Cooperation and Promotion Mechanism under One Belt One Road. April 2019. Available online: http:/ /58.194.172.13/rwt/157/http/MNYXC5DDMFZC65UTMSST6Z5P/datum/info?id=84 (accessed on 19 March 2021).

27. Zhou, L.H.; Gilbert, S.; Wang, Y.; Cabre, M.M.; Gallagher, K.P. Moving the Green Belt and Road Initiative: From Words to Actions. 8 November 2018. Available online: https:/ / www.bu.edu/gdp/files/2018/11/GDP-and-WRI-BRI-MovingtheGreenbelt.pdf (accessed on 19 March 2021).

28. MCC. Guidelines for Country-by-Country (Region-by-Region) Foreign Investment and Cooperation. 2020. Available online: http: / fec.mofcom.gov.cn/article/gbdqzn/ (accessed on 15 March 2021).

29. UN. Transforming Our World: The 2030 Agenda for Sustainable Development. 2015. Available online: https://sdgs.un.org/2030 agenda (accessed on 15 March 2021).

30. Dong, L.; Xiaohua Yang, X.H.; Li, H.T. The Belt and Road Initiative and the 2030 Agenda for Sustainable Development: Seeking Linkages for Global Environmental Governance. Chin. J. Popul. Resour. Environ. 2018, 16, 203-210. [CrossRef]

31. CССPC and the State Council. Overall Reform Plan for Promoting Ecological Civilization. Available online: http:/ /www.gov.cn/ guowuyuan/2015-09/21/content_2936327.htm (accessed on 7 February 2021).

32. The Guardian. China Strengthens Environmental Laws. 25 April 2014. Available online: https://www.theguardian.com/ environment/2014/apr/25/china-strengthens-environmental-laws-polluting-factories (accessed on 7 February 2021).

33. Heggelund, G.M. China's Climate and Energy Policy: At a Turning Point? Int. Environ. Agreem. Politics Law Econ. 2021, 21, 9-23. [CrossRef] [PubMed]

34. China Daily. Full Text of Xi Jinping's Report at 19th CPC National Congress. 14 November 2017. Available online: www. chinadaily.com.cn/china/19thcpcnationalcongress/2017-11/04/content_34115212.htm (accessed on 7 February 2021). 
35. MCC; MEP. The Guidelines for Environmental Protection in Foreign Investment and Cooperation. 18 February 2013. Available online: http:/ / english.mofcom.gov.cn/article/policyrelease/bbb/201303/20130300043226.shtml (accessed on 15 March 2021).

36. CCCMC. Guidelines for Social Responsibility in Outbound Mining Investments. 15 March. Available online: http:/ /www.cccmc. org.cn/docs/2017-08/20170804141709355235.pdf (accessed on 7 April 2021).

37. MEEC; MFA, NDRC and MCC. Guidance on Promoting Green Belt and Road. 24 April 2017. Available online: http:/ / english mee.gov.cn/Resources/Policies/policies/Frameworkp1/201706/t20170628_416864.shtml (accessed on 7 February 2021).

38. MEEC. The Belt and Road Ecological and Environmental Cooperation Plan. 12 May 2017. Available online: http:// english.mee. gov.cn/Resources/Policies/policies/Frameworkp1/201706/t20170628_416869.shtml (accessed on 7 February 2021).

39. NDRC; SOA. Vision for Maritime Cooperation under the Belt and Road Initiative. 19 June 2017. Available online: http: / / english.mee.gov.cn/News_service/media_news/201706/t20170621_416432.shtml (accessed on 7 February 2021).

40. Newsroom City of London. Green Belt and Road Principles Receive Industry Backing. 24 April 2019. Available online: https:/ / news.cityoflondon.gov.uk/green-belt-and-road-principles-receive-industry-backing/ (accessed on 15 March 2021).

41. Gu, A.; Zhou, X.Y. Emission Reduction Effects of the Green Energy Investment Projects of China in Belt and Road Initiative Countries. Ecosyst. Health Sustain. 2020, 6, 1747947. [CrossRef]

42. China Daily. China Officially Launches Green Development Coalition under BRI. 25 April 2019. Available online: http: //www.chinadaily.com.cn/a/201904/25/WS5cc181c5a3104842260b8626.html (accessed on 28 February 2021).

43. BRI International Green Development Coalition. Available online: http://eng.greenbr.org.cn/icfgd/ (accessed on 17 April 2021).

44. BRIGC. Belt \& Road Green Development Case Study Report. 17 October. Available online: http://eng.greenbr.org.cn/icfgd/ research/8a7beee86d705a33016dd90a8e6f00b1.html (accessed on 6 April 2021).

45. Salacuse, J.W.; Sullivan, N.P. Do BITs Really Work: An Evaluation of Bilateral Investment Treaties and Their Grand Bargain. Harv. Int. Law J. 2005, 46, 67.

46. Gazzini, T. Bilateral Investment Treaties and Sustainable Development. J. World Invest. Trade 2014, 15, 929. [CrossRef]

47. MCC. The List of Bilateral Investment Treaties Signed by China. 12 December 2016. Available online: http://tfs.mofcom.gov.cn/ article/Nocategory/201111/20111107819474.shtml (accessed on 6 April 2021).

48. Ronald, B.M. The IEA Database Project 2002-2020. Available online: https:/ / iea.uoregon.edu/ (accessed on 8 April 2021).

49. The World Bank. Environmental and Social Framework (ESF). 1 October 2018. Available online: https://www.worldbank.org/ en/projects-operations / environmental-and-social-framework (accessed on 18 March 2021).

50. Cheremeteff, F.; Broekhoven, G.; Khmeleva, E.; Shvarts, E.A.; Simonov, E.A.; Dolinina, Y. International Environmental Law and China's Belt and Road Initiative Development: Environmental Challenges, Risks and Opportunities. In Proceedings of the Practical Geography and XXI Century Challenges, Moscow, Russia, 4-6 June 2018. [CrossRef]

51. Laurens, N.; Morin, J.F. Negotiating Environmental Protection in Trade Agreements: A Regime Shift or a Tactical Linkage? Int. Environ. Agreem. Politics Law Econ. 2019, 19, 533-556. [CrossRef]

52. Gleason, T. Examining Host-State Counterclaims for Environmental Damage in Investor-State Dispute Settlement from Human Rights and Transnational Public Policy Perspectives. Int. Environ. Agreem. Politics Law Econ. 2020, 27, 427-444. [CrossRef]

53. Pisupati, B. Role of Multilateral Environmental Agreements (MEAs) in Achieving the Sustainable Development Goals (SDGs). United Nations Environment Programme (UNEP). 1 April 2016. Available online: https://www.unep.org/resources/report/ role-multilateral-environmental-agreements-achieving-sustainable-development-goals (accessed on 9 April 2021).

54. Escobar-Pemberthy, N.; Ivanova, M. Implementation of Multilateral Environmental Agreements: Rationale and Design of the Environmental Conventions Index. Sustainability 2020, 12, 7098. [CrossRef]

55. Convention on the Protection and Use of Transboundary Watercourses and International Lakes. Available online: https:/ / unece.org/environment-policy/water/about-the-convention/introduction (accessed on 16 April 2021).

56. UNECE Espoo Environmental Impact Assessment Convention (Espoo, 25 February 1991; in Force on 10 September 1997). Available online: https:/ / unece.org/fileadmin/DAM/env/eia/eia.htm (accessed on 16 April 2021).

57. Protocol on Strategic Environmental Assessment (Kiev, 21 May 2003; in force on 11 July 2010). Available online: https:/ / unece. org/fileadmin/DAM/env/eia/documents/legaltexts/protocolenglish.pdf (accessed on 16 April 2021).

58. UNECE Convention on Access to Information, Public Participation in Decision-making and Access to Justice in Environmental Matters (Aarhus, 25 June 1998; in Force on 30 October 2001). Available online: https:/ / unece.org/environment-policy/publicparticipation/aarhus-convention/introduction (accessed on 16 April 2021).

59. Convention on the Conservation of Migratory Species of Wild Animals (Bonn, 23 June 1979; in Force on 1 November 1983). Available online: https:/ / www.cms.int/en/legalinstrument/cms (accessed on 16 April 2021).

60. Rivers Without Boundaries. 2016. Green Silk Road Initiative Declaration. 6 December 2016. Available online: http://www. transrivers.org/2016/1841/ (accessed on 9 April 2021).

61. Xinhua News. 2018. China Launches Big Earth Data Project. 13 February 2018. Available online: http://www.xinhuanet.com/ english/2018-02/13/c_136972709.htm (accessed on 9 April 2021).

62. Feehily, R. Neutrality, Independence and Impartiality in International Commercial Arbitration, a Fine Balance in the Quest for Arbitral Justice. Penn State J. Law Int. Aff. 2019, 7, 88.

63. UNCITRAL. Convention on the Recognition and Enforcement of Foreign Arbitral Awards. 1958. Available online: https://uncitral.un.org/en/texts/arbitration/conventions/foreign_arbitral_awards (accessed on 12 April 2021). 
64. Utterback, M.; Li, R.; Blackwell, H. Enforcing Foreign Arbitral Awards in China-A Review of the Past Twenty Years. 15 September 2016. Available online: https://www.kwm.com/en/knowledge/insights/enforcing-foreign-arbitral-awards-in-china-20160915 (accessed on 12 April 2021).

65. Bishop, R.D.; Crawford, J.R.; Reisman, W.M. Foreign Investment Disputes: Cases, Materials and Commentary; Kluwer: Alfen am Rhein, The Netherlands, 2014.

66. Directive 2004/35/EC of 21 April 2004 on Environmental Liability with Regard to the Prevention and Remedying of Environmental Damage, [2004] OJ L143/56, Annex II. Available online: https:/ / eur-lex.europa.eu/LexUriServ/LexUriServ.do?uri=OJ:L:2004: 143:0056:0075:en:PDF (accessed on 18 September 2021).

67. Comprehensive Environmental Response, Compensation and Liability Act, 42 USC §§ 9601-9675. Available online: https: / / uscode.house.gov/view.xhtml?path=/prelim@title42/chapter103\&edition=prelim (accessed on 18 September 2021).

68. Chinese Civil Code (Effective 1 January 2021). Available online: http:/ /www.npc.gov.cn/npc/c30834/202006/75ba6483b8344591 abd07917e1d25cc8.shtml (accessed on 17 April 2021).

69. Chinese State Council. Reform Plan for Ecological Environment Damage Compensation System. 18 December 2017. Available online: http:/ / www.gov.cn/zhengce/2017-12/17/content_5247952.htm (accessed on 17 April 2021).

70. Protocol of 1992 to Amend the International Convention on Civil Liability for Oil Pollution Damage (London, 27 November 1992; in force on 30 May 1996). Available online: https:/ / treaties.un.org/doc/Publication/UNTS/Volume\%201956/v1956.pdf (accessed on 18 September 2021).

71. Nagoya-Kuala Lumpur Supplementary Protocol on Liability and Redress to the Cartagena Protocol on Biosafety (Nagoya, 15 October 2010; in force on 5 March 2018). Available online: https:/ treaties.un.org/doc/Treaties/2010/12/20101215\%2005-26\%2 0PM/Ch_27_8_c.pdf (accessed on 18 September 2021). 